\title{
Sumber Daya Pendukung Keberhasilan Pelaksanaan Kurikulum
}

\author{
Maimunah, M.Pd.I \\ Dosen Jurusan Manajemen Pendidikan Islam Fakultas Ilmu Agama \\ Islam, Universitas indragiri (UNISI) Tembilahan
}

\begin{abstract}
Abstrak
Kurikulum dipandang sebagai suatu rencana yang disusun untuk melancarkan proses belajar mengajar di bawah bimbingan dan tanggungjawab sekolah atau lembaga pendidikan beserta staf pengajarnya. Hakikatnya setiap kurikulum merupakan suatu cara untuk mempersiapkan anak agar berpartisipasi sebagai anggota yang produktif dalam masyarakat. setiap kurikulum, bagaimanapun polanya, selalu memiliki komponen-komponen tertentu, yakni pernyataan tentang tujuan dan sasaran, seleksi dan organisasi bahan dan isi pelajaran, bentuk dan kegiatan belajar dan mengajar, dan akhirnya evaluasi hasil belajar. Perbedaan kurikulum terletak pada penekanan pada unsur-unsur tertentu. Keberhasilan pelaksanaan kurikulum di sekolah tidak terlepas dari beberapa sumber daya pendukung, sumber daya pendukung keberhasilan pelaksanaan kurikulum di antaranya adalah: manajemen sekolah, pemanfaatan sumber belajar, penggunaan media pembelajaran.
\end{abstract}

Key words: Sumber Daya Pendukung, Kurikulum

\section{A. Pendahuluan}

Salah satu upaya membina dan membangun generasi muda yang tangguh dan mumpuni diantaranya adalah melalui pendidikan, baik yang diberikan dalam lingkungan keluarga, melalui pendidikan formal di sekolah, maupun pendidikan dalam lingkungan masyarakat. Oleh karena itu sekolah sebagai lembaga pendidikan formal harus ditentukan oleh adanya pelaksanaan kurikulum sekolah itu. Keberhasilan sumber daya manusia dalam segi pendidikan sangat dipengaruhi oleh adanya pemahaman seluruh personal di sekolah itu dalam melaksanakan kurikulum.

Secara teoritis, kurikulum pendidikan dasar dan menengah wajib memuat: pendidikan agama, pendidikan kewarganegaraan, bahasa, matematika, ilmu pengetahuan alam, ilmu pengetahuan sosial, seni dan budaya, pendidikan jasmani dan olah raga, keterampilan 
atau kejuruan. (UUSPN No. 20 tahun 2003 pasal 37 ayat 1). Pada dasarnya kurikulum adalah suatu cara untuk mempersiapkan siswa agar berpartisipasi sebagai anggota yang produktif dalam masyarakatnya. Dalam kurikulum berbasis kompetensi (KBK) mengenai sasaran penelitian dan pengembangan kurikulum adalah diperolehnya kompetensi lulusan yang sesuai dengan berbagai tuntutan pasar. KBK kemudian mendapat tanggapan, kritik dan saran dari pada praktisi serta masyarakat mengenai substansi isi kurikulum tersebut sehingga dikembangkan kurikulum tingkat satuan pendidikan (KTSP) yang diharapkan menjadi lebih baik dan sesuai perkembangan ilmu dan teknologi serta sesuai dengan semangat desentralisasi. Seluruh komponen bangsa ikut memberikan dorongan bagi penyelenggara pendidikan untuk selalu melakukan proses perbaikan, modifikasi, dan evaluasi pada kurikulum yang digunakan.

Di dalam proses pengendalian mutu pendidikan, kurikulum merupakan perangkat yang sangat penting karena menjadi dasar untuk menjamin kompetensi keluaran dari proses pendidikan. Kurikulum harus selalu diubah secara periodik untuk menyesuaikan dengan dinamika kebutuhan pengguna dari waktu ke waktu.

\section{B. Pembahasan}

a. Manajemen Sekolah

1. Pengertian Manajemen Sekolah

Pengertian manajemen menurut Kathryn M. Bartol dan David C. Martin (1995), adalah proses untuk mencapai tujuan-tujuan organisasi dengan melakukan kegiatan dari empat fungsi utama, yaitu merencanakan (planning), mengorganisasikan (organizing), memimpin (leading), dan mengendalikan (controlling). Dengan demikian, manajemen adalah sebuah kegiatan yang berkesinambungan, terus menerus dan saling keterkaitan. ${ }^{1}$

Dalam konteks pendidikan, menurut Djam'an Satori (1980) manajemen pendidikan merupakan "keseluruhan proses kerja sama dengan menfaatkan semua sumber personel dan material yang tersedia dan sesuai untuk mencapai

1 Rusman, Manajemen Kurikulum (Jakarta : PT Remaja Grafindo Persada, 2009), hlm. 121. 
tujuan pendidikan yang telah diterapkan secara efektif dan efesien”. Sementara itu, Hadari Namawi (1992) mengemukakan bahwa"majemen pendidikan sebagai rangkaian kegiata atau keseluruhan proses pengendalian usaha kerja sama sejumlah orang untuk mencapai tujuan pendidikan secara sistmatis diselenggarakan di lingkungan tertentu terutama berupa lembaga pendidikan formal. ${ }^{2}$

Dari sekian banyak pengertian manajemen pendidikan dapat ditarik benang merah bahwa: (1) manajemen peendidikan merupakan suatu kegiatan, (2) manajemen pendidikan memfaatkan berbagai sumber daya, dan (3) manajemen pendidikan berupaya untuk mencapai tujuan pendidikan yang telah ditetapkan. ${ }^{3}$

2. Fungsi Manajemen

Menurut G.R Terry tedapat empat fungsi manajemen, yakni: (1) planning (perencanaan), Perencanaan merupakan penentuan kegiatan yang akan dilaksanakan pada masa depan, (2) organizing (pengorganisasian), adalah tahap yang dilalui setelah perencanaan yaitu kegiatan pengorganisasian kegiatan ini menjembatani antara kegiatan perencanaa dengan kegitan pengerakan(3) actuating (pelaksanaan), setelah adanya pelening dan pengorganisasian maka tahap selanjut nya adalah Actuiting pengorganisasian secara kongrit (4) controlling (pengawasan). ${ }^{4}$ Pengawasan kegiatan yang telah dilaksanakan. Di antara fungsi manajemen ialah :

1. Bidang Kegiatan Pendidikan ${ }^{5}$

a. Manajemen kurikulum

b. Manajemen kesiswaan

c. Manajemen personalia

d. Manajemen keuangan

e. Manajemen perawatan sarana dan prasarana sekolah

2 Ibid

3 Ibid. hlm. 122.

4 Ibid

5 Ibid. hlm 127. 


\section{$8 \quad \frac{\text { Jurnal AL-AFKAR }}{\text { Vol. III, No. II, Oktober } 2014}$}

2. Tujuan Manajemen pendidikan ${ }^{6}$
a. Produktivitas
b. Kualitas
c. Efektivitas
d. Efisiensi

3. Prinsip Manajemen ${ }^{7}$

a. Prinsip manajemen berdasarkan sasaran

b. Prinsip manajemen berdasarkan orang

c. Prinsip manajemen berdasarkan informa

b. Pemanfaatan Sumber Belajar

1. Pengertian Sumber Belajar

Sumber belajar merupakan salah satu komponen yang membantu dalam proses belajar mengajar. Sumber belajar tidak lain adalah daya yang dapat dimanfaatkan guna kepentingan proses belajar mengajar, baik secara langsung maupun tidak langsung, sebagian atau secara keseluruhan. ${ }^{8}$

2. Makna Sumber Belajar

Pendidikan konvensional memiliki paradigma bahwa guru adalah satu-satunya sumber belajar, sehingga dianggap orang yang paling memiliki pengetahuan.paradigma itu kenudian bergeser menjadi guru lebih dahulu tahu. Namun, sekarang dengan perkembangan ilmu dan teknologi bukan saja pengetahuan guru biasa sama dengan murid, bahkan murid biasa lebih dahulu tahu daripada gurunya. Itu semua dapat terjadi akibat perkembangan media informasi disekitar kita sehingga pada saat ini guru bukan lagi satu-satunya sumber belajar, melainkan guru memiliki fungsi lebih luas yaitu sebagai penyedia fasilitas belajar agar siswa mau belajar. ${ }^{9}$

3. Fungsi Sumber Belajar

Sumber belajar memiliki fungsi yang sangat penting

6 Aan Komariah, Manajemen Pendidikan ( Bandung : Bumi Aksara, 2009), hlm. 88.

7 Ibid. hlm. 90

8 Loc cit. hlm. 130.

9 Ibid. hlm. 131. 
dalam kegiatan pembelajaran. Kalau media pembelajaran sekedar media untuk menyampaikan pesan, sedangkan sumber belajar tidah hanya memiliki fungsi tersebut, tetapi juga termasuk strategi, metode, dan tekniknya. ${ }^{10}$

4. Manfaat Sumber Belajar ${ }^{11}$

a. Manfaat sumber belajar, yaitu untuk memberikan pengalaman belajar yang konkret tidak langsung.

b. Menyajikan sesuatu yang tidak mungkin diadakan, dikunjungi, atau dilihat secara langsung dan konkret, menambah dan memperluas cakrawala sajian yang ada di dalam kelas, memberikan informasi yang akurat dan yang terbaru, seperti buku teks, ensiklopedi, narasumber, dan lain-lain.

c. Membantu memecahkan masalah pendidikan dan pembelajaran baik dalam lingkungan makro maupun lingkungan mikro.

d. Memberikan motivasi yang positif, lebih-lebih bila dirancang penggunaannya secara tepat.

e. Merangsang untuk berfikir, bersikap, dan berkembang lebih lanjut, seperti buku teks, buku bacaan, film, dan lainnya yang mengandung daya penalaran yang mampu membuat siswa terangsang untuk berfikir, menganalisis dan berkembang lebih lanjut.

5. Kriteria memilih sumber belajar

Pemilihan sumber belajar secara umum terdiri dari dua macam ukuran, yaitu kriteria umum dan kriteria berdasarkan tujuan yang hendak dicapai. ${ }^{12}$

a. Kriteria umum

Kriteria umum merupakan ukuran kasar dalam memilih sumber belajar diantaranya adalah:

a) ekonomis dalam pengertian murah,

b) praktis dan sederhana,

c) mudah diperoleh,

10 Ibid. hlm. 134.

11 Ibid. hlm 135.

12 Ibid. hlm. 136. 


\section{$10 \frac{\text { Jurnal AL-AFKAR }}{\text { Vol. III, No. II, Oktober } 2014}$}

d) bersifat fleksibel,

e) komponen-komponennya sesuai dengan tujuan.

b. Kriteria berdasarkan tujuan

Beberapa kriteria memilih sumber belajar berdasarkan tujuan diantaranya adalah:

a) Sumber belajar guna memotivasi

b) Sumber belajar untuk pembelajaran

c) Sumber belajar untuk penelitian

d) Sumber belajar untuk memecahkan masalah

e) Sumber belajar untuk presentasi

6. Klasifikasi sumber belajar

Secara garis besar sumber belajar dapat dibedakan menjadi dua jenis berikut. ${ }^{13}$

- Sumber belajar yang dirancang atau lerning resources by design, yakni sumber-sumber yang secara khusus dirancang atau dikembangkan sebagaai "komponen sistem instrusional" untuk memberikan fasilitas belajar yang terarah dan bersifat formal.

- Sumber belajar yang dimanfaatkan atau learning resources by utilization, yakni sumber belajar yang tidak didesain khusus untuk keperluan pembelajaran dan keberadaanya dapat ditemukan, ditetapkan, dan dimanfaatkan untuk keperluan pembelajaran.

Jenis-jenis sumber belajar

Association for Educational Communication and Technology (AECT) membedakan enam jenis sumber belajar yang dapat digunakan dalam proses belajar sebagai berikut: ${ }^{14}$
a. Pesan (message)
b. Orang (people)
c. Bahan (materials)
d. Alat (device)
e. Teknik
f. Latar (setting)

7. Pemanfaatan sumber belajar dalam implementasi

13 Ibid. hlm. 137. 
kurikulum di sekolah. ${ }^{15}$

a. Berbagai sumber belajar yang dapat dioptimalkan

Sebagai ilustrasi dapat dikemukakan disini beberapa contoh pemanfatan benda-benda atau alat-alat yang dapat digunakan sebagai sumber belajar disekolah.

1. Barang bekas (BABE), sering kali luput dari perhatian kita, padahal dapat dimanfaatkan secara optimal dalam proses pembelajaran.

2. Realita di sekitar (kebun sekolah, rumah, pemukiman), realita yang paling sederhana yang dilihat oleh siswa sehari-hari adalah mengangkat pengalaman perjalanan mereka ke sekolah.

3. Benda-benda yang mempunyai 'Nilai khusus', setiap siswa sudah dapat dipastikan memiliki kesayangan terhadap benda-benda tertentu sehingga diperlakukan sebagai sesuatu yang memiliki nilai khusus.

8. Strategi Merancang Sumber Belajar

Strategi dalam merancang sumber belajar, seorang guru harus mampu mengindetifikasi berbagai karakteristik sumber belajar yang digunakan. ${ }^{16}$

Langkah-langkah yang harus dilakukan adalah sebagai berikut:

a. Guru harus mengindefikasi karakteristik sumber belajar yang akan digunakan

b. Sumber belajar yang ada sangatlah banyak, untuk itu guru harus mampu mengindetifikasi karakteristik dari masing-masing sumber belajar yang digunakan.

c. Sumber belajar yang digunakan disesuaikan dengan tujuan pembelajaran

d. Sumber belajar yang digunakan disesuaikan dengan kemampuan guru .

e. Dalam merancang sumber belajar, seorang guru harus memahami kemampuan dalam hal menggunakan sumber belajar.

15 Ibid. hlm. 139.

16 Ibid. hlm. 143. 


\section{$12 \frac{\text { Jurnal AL-AFKAR }}{\text { Vol. III, No. II, Oktober } 2014}$}

f. Sumber belajar yang digunakan disesuaikan dengan kebutuhan siswa.

g. Hal terpenting dalam merancang sumber belajar adala menyesuaikan dengan kebutuhan siswa.

9. Prinsip-prinsip Merancang Sumber Belajar

Prinsip dalam merancang sumber belajar dapat dilihat dari karakteristik sumber belajar itu sendiri, dimana kedudukan sumber belajar yang digunakan dapat berfungsi sebagai berikut.
a. Total teaching
b. Major resources
c. Suplemen view

Pada prinsipnya perancangan sumber belajar dibagi ke dalam dua kategori berikut:
a. Sumber belajar by design
b. Sumber belajar by utilization

10. Prosedur Merancang Sumber Belajar ${ }^{17}$

\section{a. Perencanaan}

Prosedur atau langkah-langkah yang harus dilakukan dalam perencanaan sumber belajar adalah sebagai berikut.

1. Analisis kebutuhan

2. Penetapan sumber belajar

3. Pengembangan sumber belajar

b. Pelaksanaan

Dalam pelaksanaan merancang sumber belajar, total teaching harus dilakukan.

11. Evaluasi Perencanaan Sumber Belajar ${ }^{18}$

a. Kriteria keberhasilan dalam merancang sumber belajar

b. Evaluasi sumber belajar

c. Penggunaan Media Pembelajaran

1. Pengertian Media Pembelajaran

Kata media berasal dari bahasa latin dan merupakan

17 Ibid. hlm. 145.

18 Ibid. hlm. 149. 
bentuk jamak dari kata medium yang secara harfiah dapat di artikan sebagai 'perantara'.

Lesle J. Briggs (1979) menyatakan bahwa media pembelajaran sebagai "the physicalmeans of conveying instructional content.....book, films, videotapes, ect." Lebih jauh briggs menyatakan media adalah "alat untuk memberi perangsang bagi peserta didik supaya terjadi proses belajar. Sementara itu, mengenai evektivitas media, Brown (1970) mengaris bawahi bahwa media yang digunakan guru atau siswa dengan baik dapat memengaruhi evektivitas program belajar mengajar. ${ }^{19}$

Dari pendapat diatas, dapat dikembangkan beberapa pemahaman tentang posisi media serta peran dan kontribusinya dalam kegiatan pembelajaran ataupun kegiatan pendidikan dan pelatihan. ${ }^{20}$

2. Kedudukan Media dalam Pembelajaran

Kedudukan media dalam komponen pembelajaran sangat ppenting bahkan sejajar dengan metode pembelajaran, karena metode yang digunakan dalam proses pembelajaran biasanya akan menuntut media apa yang dapat diintegrasikan dan diadptasikan dengan kondisi yang dihadapi. Maka, kedudukan media dalam suatu pembelajaran sangatlah penting dan menentukan. ${ }^{21}$

Dalam proses pembelajaran terdapat tingkatan prroses aktivitas yang mellibatkan keberadaan media pembelajaran, yaitu (1) tingkat peengolahan informasi, (2) tingkat penyampaian inforrmasi, (3) tingkat penerimmaaan informasi, (4) tingkat respons dari siswa, (5) tingkat diagnosis dari guru, (6) tingkat penilaian, dan (7) tingkat penyampaian hasil.

3. Jenis-jenis Media Pembelajaran

Ada tiga jenis media pembelajaran :
a. Auditif
b. Visual

19 Ibid. hlm. 151.

$20 \mathrm{Ibid}$

21 Ibid. hlm. 153. 


\section{$14 \frac{\text { Jurnal AL-AFKAR }}{\text { Vol. III, No. II, Oktober } 2014}$}

c. Kinestetik

\section{Prosedur Pemilihan Media}

Ada beberapa prinsip yang perlu ddiperhatikan dalam pemilihan media pembelajaran, meskipun caranya berbeda beda. Namun demikian, ada hal yang seragam bahwa setiap media pembelajaran memiliki kelebihan dan kekurangaan yang akan memberikan pengaruh kepada efektivitas program pembelajaran.

5. Karakteristik Media
a. Media grafis
b. Gambar/Foto
c. Digram
d. Bagan
e. Grafik (Graph) 22
f. Media Display

1. Papan tulis/white board

2. Papan flanel

3. Flip chart

4. Gambar mati yang diproyeksikan

5. Media audio

6. Media komputer

7. Pemanfaatan internet sebagai media pembelajaran

8. Penggunaan internet dalam pembelajaran

9. Manajemen sistem informasi ${ }^{23}$

\section{Kesimpulan}

Dari pembahasan di atas, dapat diambil beberapa kesimpulan:

1. Kurikulum dipandang sebagai suatu rencana yang disusun untuk melancarkan proses belajar mengajar di bawah bimbingan dan tanggungjawab sekolah atau lembaga pendidikan beserta staf pengajarnya.

22 Grafik adalah pnyajian kembali data-data yang berupa angka-angka dalam bentuk visual simbolis (lambang visual). Jenis grafik diantaranya sebagai berikut: Grafik garis (line graph) dan Grafik batang.

23 Eko Nugroho, Sistem Informasi Manajemen, Konsep Aplikasi dan Perkembangannya (Yogyakarta, Andi Ofset: 2008) hlm. 31. 
2. Hakikat setiap kurikulum merupakan suatu cara untuk mempersiapkan anak agar berpartisipasi sebagai anggota yang produktif dalam masyarakat. setiap kurikulum, bagaimanapun polanya, selalu memiliki komponen-komponen tertentu, yakni pernyataan tentang tujuan dan sasaran, seleksi dan organisasi bahan dan isi pelajaran, bentuk dan kegiatan belajar dan mengajar, dan akhirnya evaluasi hasil belajar. Perbedaan kurikulum terletak pada penekanan pada unsur-unsur tertentu.

3. Keberhasilan pelaksanaan kurikulum di sekolah tidak terlepas dari beberapa sumber daya pendukung, sumber daya pendukung keberhasilan pelaksanaan kurikulum di antaranya adalah: manajemen sekolah, pemanfaatan sumber belajar, penggunaan media pembelajaran.

\section{Daftar Pustaka}

Aan Komariah, Manajemen Pendidikan, Bandung: Bumi Aksara. 2009 Ali, H.M. Pengembangan Kurikulum di sekolah. Bandung: Sinar Baru. 2004.

Alisyahbana, Armida S. Otonomi Daerah dan Desentralisasi Pendidikan, Dalam Jurnal Analisis Sosial Vol 5 No. 1 Januari 2000.

Arikunto, Suharsimi \& Yuliana Lia. Manajemen Pendidikan Yogyakarta, Aditiya media Yogyakarta. 2009

Rusman, Manajemen Kurikulum, Jakarta PT Remaja grafindo Persada 2009 